in vivo $34: 1701-1714(2020)$

doi:10.21873/invivo.11964

Review

\title{
How to Choose Between Percutaneous Transhepatic and Endoscopic Biliary Drainage in Malignant Obstructive Jaundice: An Updated Systematic Review and Meta-analysis
}

\author{
ALESSANDRO RIZZO, ANGELA DALIA RICCI, GIORGIO FREGA, ANDREA PALLONI, \\ STEFANIA DE LORENZO, FRANCESCA ABBATI, VERONICA MOLLICA, \\ SIMONA TAVOLARI, MARIACRISTINA DI MARCO and GIOVANNI BRANDI \\ Department of Experimental, Diagnostic and Specialty Medicine, \\ S. Orsola-Malpighi University Hospital, Bologna, Italy
}

\begin{abstract}
Background/Aim: Malignant obstructive jaundice (MOJ) is a common condition caused by several primary and secondary cancers. We performed a systematic review and meta-analysis to investigate technical success rate and safety of percutaneous transhepatic biliary drainage (PTBD) versus endoscopic biliary drainage (EBD) in MOJ. Materials and Methods: Relevant trials were identified by searching electronic databases and conference meetings. We included thirteen retrospective studies and four randomized controlled trials, with PTBD performed in 2353 patients and EBD in 8178 patients. Outcomes of interest included: technical success rate, overall complications, 30-day mortality rate and risk of bleeding, pancreatitis, cholangitis and tube dislocation. Results: The differences in technical success rate, total complications, 30-day mortality rate and tube dislocation were not statistically significant between the two groups. Patients receiving PTBD showed a lower risk of pancreatitis $(O R=0.14$, 95\%CI=0.06-0.31) and cholangitis $(O R=0.52,95 \% C I=0.30$ $0.90)$ when compared to EBD while PTBD was associated with higher risk of bleeding (OR=1.78; 95\%CI=1.32-2.39). Conclusion: Our meta-analysis indicates the presence of some advantages and limits for both PTBD and EBD. We highlight the paucity of quality-of-life data, a vital element which should
\end{abstract}

This article is freely accessible online.

Correspondence to: Rizzo Alessandro, Medical Doctor, Division of Medical Oncology, S. Orsola-Malpighi Hospital, University of Bologna, Bologna, Italy. Tel: +39 0512144078, Fax: +39 0516364037,e-mail: rizzo.alessandro179@gmail.com

Key Words: Malignant obstructive jaundice, percutaneous transhepatic biliary drainage, endoscopic biliary drainage, pancreatic cancer, cholangiocarcinoma. be carefully pondered in future studies and in choosing the optimal technique in patients with MOJ.

Patency of the biliary tree and the related drainage of bile are crucial elements in the physiologic hepatic function $(1,2)$; in biliary obstructions, bile ducts cannot deliver bile to duodenum resulting in hyperbilirubinemia, toxic accumulation of bile salts and jaundice $(3,4)$. If choledocholithiasis represents the leading cause of benign biliary obstruction, obstructive jaundice is a common finding in several malignancies, especially in advanced disease (5). Nevertheless, in a not insignificant number of cases, obstructive jaundice is related to an underlying neoplasm at an early, resectable stage where jaundice constitutes one of the first signs (6). Obstructions may arise at any level within the biliary tree and malignant obstructive jaundice (MOJ) can occur following primary cancers (e.g. pancreatic cancer, cholangiocarcinoma, hepatocellular carcinoma, gallbladder cancer, etc.), lymph nodal compressions or liver metastases $(7,8)$. Given the deleterious effects caused by the gradual and inexorable increase of hyperbilirubinemia, biliary drainage is usually performed with the aim of relieving symptoms, improving quality of life and restoring serum biochemistry to normal, an essential element for palliative systemic chemotherapy, palliative radiotherapy or surgical resection, when feasible (9). Procedures of biliary drainage comprise surgical bypass and extensively used palliative techniques such as percutaneous transhepatic biliary drainage (PTBD) and endoscopic biliary drainage (EBD), each with its specific advantages and limits $(10,11)$. The choice of the optimal technique in patients with MOJ is based on several factors including site of obstruction (e.g. proximal or distal), the expected survival, the purpose of drainage, the postprocedural therapeutic strategies and the level of expertise of the center $(12,13)$. In this landscape, the presence of a multidisciplinary 
Table I. Main characteristics of the included studies.

\begin{tabular}{|c|c|c|c|c|c|c|}
\hline Author/year & $\begin{array}{c}\text { Study design } \\
\text { and quality assessment }\end{array}$ & Malignancy type & $\begin{array}{l}\text { Carry out country } \\
\text { in analysis }\end{array}$ & No. PTBD & No. EBD & Outcomes included \\
\hline $\begin{array}{l}\text { Speer (1987) } \\
\text { (17) }\end{array}$ & $\mathrm{RCT} / 4$ & $\begin{array}{c}\text { Pancreatic carcinoma, } \\
\text { gallbladder cancer, } \\
\text { ICC, ECC }\end{array}$ & England & 36 & 39 & $\begin{array}{l}\text { - Technical success rate } \\
\text { - Risk of overall complications } \\
\text { - 30-day mortality rate } \\
\text { - Bleeding } \\
\text { - Cholangitis }\end{array}$ \\
\hline $\begin{array}{l}\text { Piñol (2002) } \\
\text { (18) }\end{array}$ & $\mathrm{RCT} / 5$ & $\begin{array}{c}\text { Pancreatic carcinoma, } \\
\text { gallbladder cancer, } \\
\text { ICC, ECC, } \\
\text { lymph node metastasis }\end{array}$ & Spain & 28 & 26 & $\begin{array}{l}\text { - Technical success rate } \\
\text { - Risk of overall complications } \\
\text { - 30-day mortality rate } \\
\text { - Pancreatitis }\end{array}$ \\
\hline $\begin{array}{l}\text { Lee (2007) } \\
\text { (19) }\end{array}$ & Retrospective/8 & $\mathrm{ECC}$ & Korea & 66 & 34 & $\begin{array}{l}\text { - Risk of overall complications } \\
\text { - 30-day mortality rate } \\
\text { - Bleeding } \\
\text { - Pancreatitis } \\
\text { - Cholangitis }\end{array}$ \\
\hline $\begin{array}{l}\text { Saluja (2008) } \\
(20)\end{array}$ & $\mathrm{RCT} / 5$ & Gallbladder cancer & India & 27 & 27 & $\begin{array}{l}\text { - Technical success rate } \\
\text { - Risk of overall complications } \\
\text { - 30-day mortality rate } \\
\text { - Cholangitis }\end{array}$ \\
\hline $\begin{array}{l}\text { Paik (2009) } \\
(21)\end{array}$ & Retrospective/8 & ECC & Korea & 41 & 44 & $\begin{array}{l}\text { - Technical success rate } \\
\text { - Risk of overall complications } \\
\text { - 30-day mortality rate } \\
\text { - Bleeding } \\
\text { - Pancreatitis } \\
\text { - Cholangitis }\end{array}$ \\
\hline $\begin{array}{l}\text { Kloek (2010) } \\
(22)\end{array}$ & Retrospective/7 & ECC & Netherlands & 11 & 90 & $\begin{array}{l}\text { - Technical success rate } \\
\text { - Risk of overall complications } \\
\text { - Bleeding } \\
\text { - Pancreatitis } \\
\text { - Dislocation } \\
\text { - Cholangitis } \\
\text { - Tube dislocation }\end{array}$ \\
\hline $\begin{array}{l}\text { Kawakami (2011) } \\
(23)\end{array}$ & Retrospective/6 & ECC & Japan & 48 & 20 & $\begin{array}{l}\text { - Risk of overall complications } \\
\text { - Pancreatitis } \\
\text { - Dislocation } \\
\text { - Cholangitis } \\
\text { - Tube dislocation }\end{array}$ \\
\hline $\begin{array}{l}\text { Cai (2011) } \\
(24)\end{array}$ & Retrospective/6 & ECC & China & 35 & 23 & $\begin{array}{l}\text { - Technical success rate } \\
\text { - Risk of overall complications } \\
\text { - Bleeding } \\
\text { - Pancreatitis } \\
\text { - Dislocation } \\
\text { - Cholangitis } \\
\text { - Tube dislocation }\end{array}$ \\
\hline $\begin{array}{l}\text { Choi (2012) } \\
(25)\end{array}$ & Retrospective/7 & $\mathrm{HCC}$ & Korea & 31 & 29 & $\begin{array}{l}\text { - Technical success rate } \\
\text { - Risk of overall complications } \\
\text { - Pancreatitis } \\
\text { - Cholangitis }\end{array}$ \\
\hline $\begin{array}{l}\text { Walter (2013) } \\
(26)\end{array}$ & Retrospective/8 & ECC & Canada & 42 & 87 & $\begin{array}{l}\text { - Technical success rate } \\
\text { - Risk of overall complications } \\
\text { - 30-day mortality rate } \\
\text { - Bleeding } \\
\text { - Cholangitis }\end{array}$ \\
\hline $\begin{array}{l}\text { Huang (2015) } \\
\text { (27) }\end{array}$ & Retrospective/7 & ECC & China & 45 & 55 & $\begin{array}{l}\text { - Risk of overall complications } \\
\text { - Cholangitis }\end{array}$ \\
\hline $\begin{array}{l}\text { Kim }(2015) \\
(28)\end{array}$ & Retrospective/8 & $\mathrm{ECC}$ & Korea & 62 & 44 & $\begin{array}{l}\text { - Technical success rate } \\
\text { - Risk of overall complications } \\
\text { - 30-day mortality rate }\end{array}$ \\
\hline
\end{tabular}


Table I. Continued

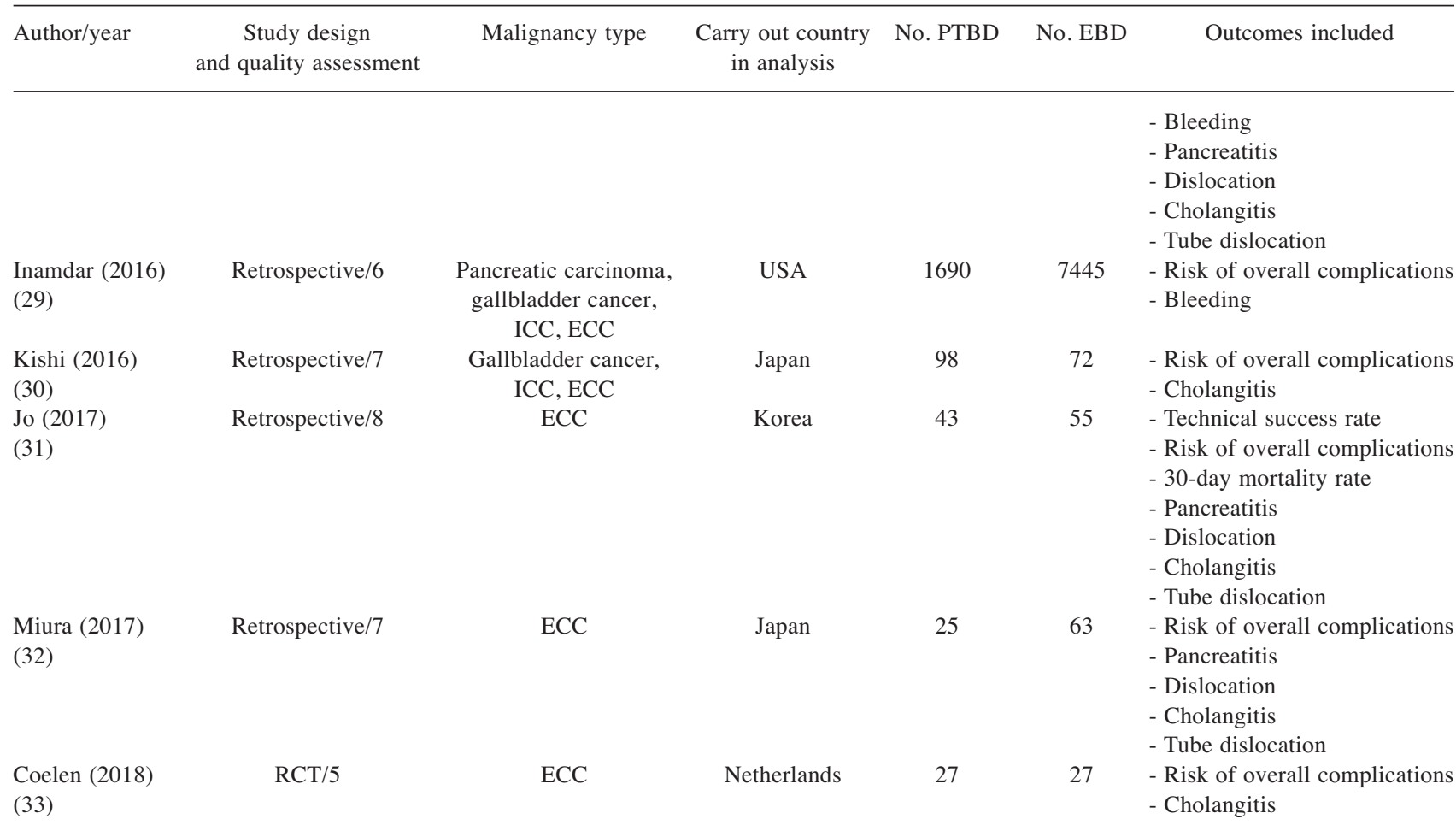

PTBD: Percutaneous transhepatic biliary drainage; EBD: endoscopic biliary drainage; RCT: randomized controlled trials; ICC: intrahepatic cholangiocarcinoma; ECC: extrahepatic cholangiocarcinoma. In RCT, quality assessment was performed using the 7-point Modified Jadad Score; the quality of non-randomized studies was evaluated using the Newcastle-Ottawa Scale.

team consisting of surgeons, interventional radiologists and medical oncologists is of vital importance (14). Due to recent advances and increased expertise in PTBD and EBD, technical success rate is currently about 90-95\% with a significant reduction in periprocedural deaths and in commonly reported complications such as bleeding, pancreatitis, cholangitis $(15,16)$.

We conducted a systematic review and meta-analysis to assess technical success rate and safety of PTBD and EBD in MOJ, focusing on seven outcomes of interest.

\section{Materials and Methods}

Search strategies. All retrospective studies and randomized controlled clinical trials (RCTs) published up to January 28, 2020, on the comparison between PTBD and EBD in MOJ were retrieved by 2 different authors. Relevant literature was searched on PubMed/Medline, Cochrane library, and EMBASE with the following phrases: "malignant obstructive jaundice" OR "malignant biliary obstruction" OR "cholangiocarcinoma" OR "biliary tract cancer" OR "pancreatic cancer" AND "drainage" OR "percutaneous transhepatic biliary drainage" OR "PTBD" OR "EBD" OR "endoscopic biliary drainage" OR "biliary stents". The search was limited to articles published in peer-reviewed journals and written in
English language. Furthermore, proceedings of the main international oncological and gastroenterology meetings (American Society of Clinical Oncology, European Society of Medical Oncology, European Council of Clinical Oncology, American Association for Cancer Research, European Association of Gastroenterology, and Asian Pacific Association of Gastroenterology), were also searched from 2000 onward for relevant abstracts. Studies selected from first analysis were then restricted to clinical studies and then reviewed by 2 authors. Systematic review and meta-analysis were conducted according to Preferred Reporting Items for Systematic Review and Meta-Analyses (PRISMA) guidelines.

Aims of the systematic review and meta-analysis. The aims of the systematic review and meta-analysis were: a) to evaluate technical success rate in patients receiving PTBD and EBD b) to compare the safety profile of PTBD and EBD.

Types of outcome measures. Outcomes of interest included: technical success rate, risk of overall complications, 30-day mortality rate and risk of bleeding, pancreatitis, cholangitis and tube dislocation.

Data extraction and synthesis. The following data were extracted for each publication: 1) study general information (author, year, study design, country); 2) malignancy type (pancreatic cancer/gallbladder cancer/intrahepatic cholangiocarcinoma/extrahepatic cholangio- 


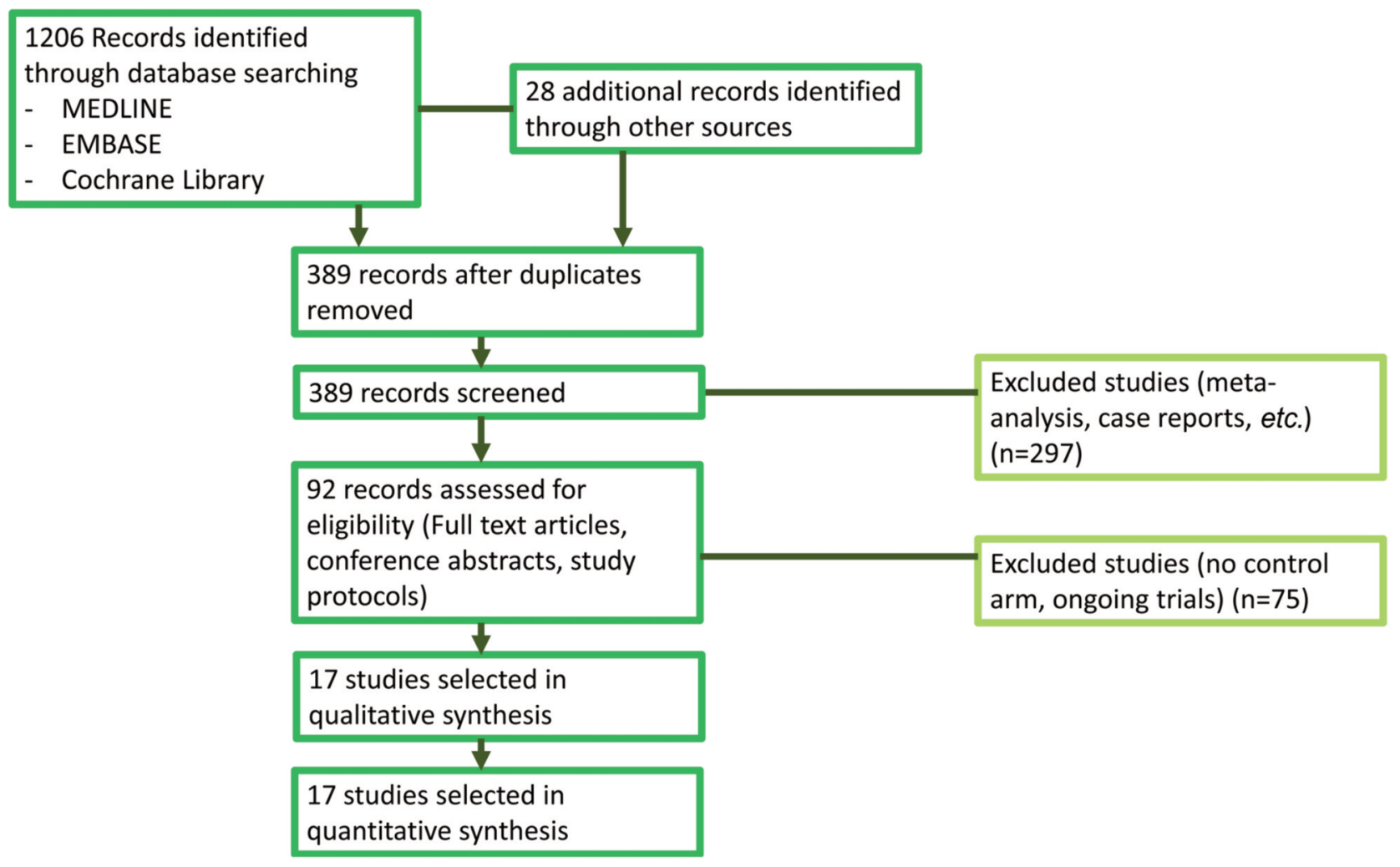

Figure 1. Study flow diagram.

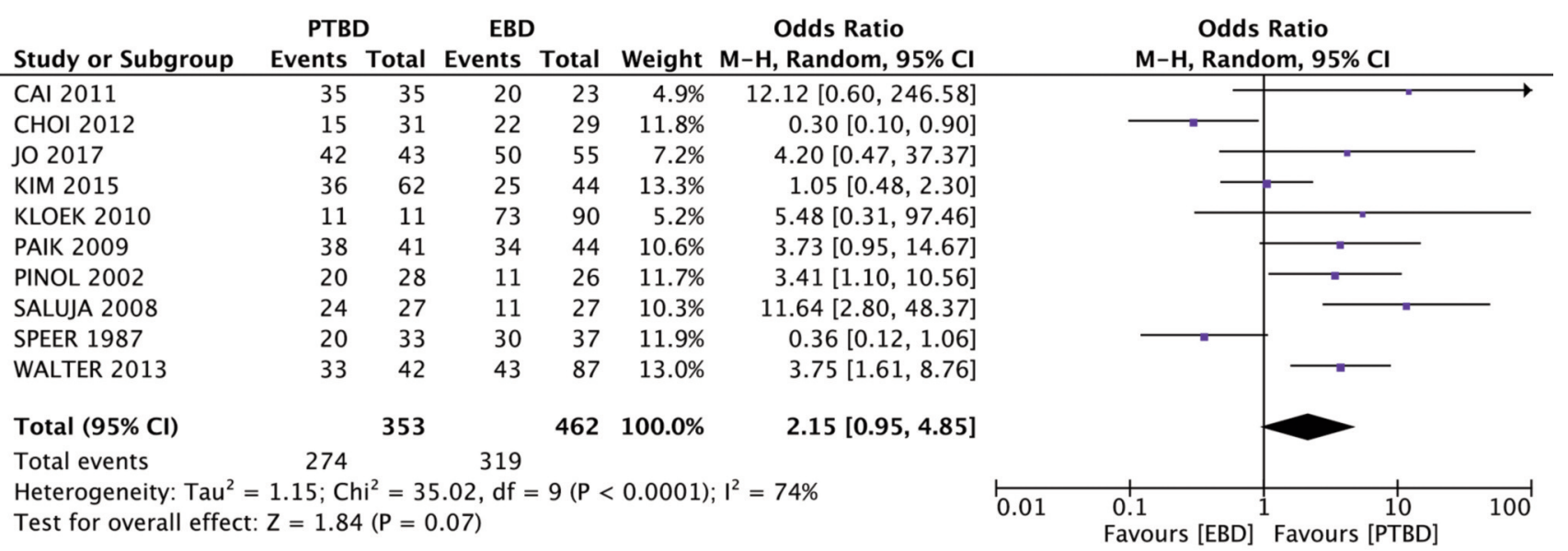

Figure 2. Forest plot of comparison between EBD and PTBD; the outcome was odds ratio (OR) of therapeutic success rate.

carcinoma/hepatocellular carcinoma/lymph node metastasis); 3) interventions; 4) number of patients; 5) available outcomes. Two separate authors conducted the search and identification independently.

Quality assessment. Two authors independently conducted quality assessment. The quality of RCTs was scored using the 7-point Modified Jadad Scale in which the descriptions of random sequence allocation concealment, blinding method and withdrawals were assessed; studies with 4 or more points were considered to be of high quality. The quality of non-randomized studies was scored using the Newcastle-Ottawa Scale (NOS), in which the selection, comparability and outcome were assessed. Studies with a score of 5 of more were interpreted as high-quality studies (Table I). 


\begin{tabular}{|c|c|c|c|c|c|c|c|c|c|c|}
\hline Study or Subgroup & \multicolumn{2}{|c|}{ PTBD } & \multicolumn{2}{|c|}{ EBD } & Weight & \multirow{2}{*}{$\begin{array}{c}\text { Odds Ratio } \\
\text { M-H, Random, 95\% Cl }\end{array}$} & \multicolumn{4}{|c|}{$\begin{array}{l}\text { Odds Ratio } \\
\mathrm{M}-\mathrm{H}, \text { Random, } 95 \% \mathrm{Cl}\end{array}$} \\
\hline CAI 2011 & 2 & 35 & 7 & 23 & $3.8 \%$ & & & & & \\
\hline CHOI 2012 & 4 & 31 & 8 & 29 & $4.8 \%$ & $0.39[0.10,1.47]$ & & & - & \\
\hline COELEN 2018 & 17 & 27 & 18 & 27 & $5.5 \%$ & $0.85[0.28,2.60]$ & & & & \\
\hline HUANG 2015 & 19 & 45 & 38 & 55 & $6.6 \%$ & $0.33[0.14,0.74]$ & & & & \\
\hline INAMDAR 2016 & 207 & 1690 & 638 & 7445 & $8.5 \%$ & $1.49[1.26,1.76]$ & & & - & \\
\hline JO 2017 & 12 & 43 & 20 & 55 & $6.4 \%$ & $0.68[0.29,1.61]$ & & & & \\
\hline KAWAKAMI 2011 & 19 & 48 & 15 & 20 & $5.3 \%$ & $0.22[0.07,0.70]$ & & & & \\
\hline KIM 2015 & 14 & 62 & 24 & 44 & $6.5 \%$ & $0.24[0.10,0.56]$ & & & & \\
\hline KISHI 2016 & 60 & 99 & 44 & 72 & $7.3 \%$ & $0.98[0.53,1.82]$ & & & - & \\
\hline KLOEK 2010 & 4 & 11 & 59 & 90 & $4.9 \%$ & $0.30[0.08,1.11]$ & & & & \\
\hline LEE 2007 & 13 & 66 & 13 & 34 & $6.2 \%$ & $0.40[0.16,0.99]$ & & & & \\
\hline MIURA 2017 & 4 & 25 & 11 & 63 & $5.1 \%$ & $0.90[0.26,3.15]$ & & & & \\
\hline PAIK 2009 & 13 & 41 & 13 & 44 & $6.2 \%$ & $1.11[0.44,2.79]$ & & & & \\
\hline PINOL 2002 & 17 & 28 & 9 & 26 & $5.5 \%$ & $2.92[0.96,8.84]$ & & & & \\
\hline SALUJA 2008 & 5 & 27 & 14 & 27 & $5.1 \%$ & $0.21[0.06,0.72]$ & & & & \\
\hline SPEER 1987 & 19 & 33 & 7 & 37 & $5.7 \%$ & $5.82[1.99,17.02]$ & & & & \\
\hline WALTER 2013 & 11 & 42 & 23 & 87 & $6.5 \%$ & $0.99[0.43,2.28]$ & & & & \\
\hline Total $(95 \% \mathrm{Cl})$ & & 2353 & & 8178 & $100.0 \%$ & $0.67[0.43,1.03]$ & & & & \\
\hline Total events & 440 & & 961 & & & & & & & \\
\hline $\begin{array}{l}\text { Heterogeneity: } \mathrm{Tau}^{2} \\
\text { Test for overall effec }\end{array}$ & $\begin{array}{l}=0.59 ; \mathrm{Cr} \\
\mathrm{Z}=1.8\end{array}$ & $\begin{array}{l}\mathrm{hi}^{2}=78 \\
1(\mathrm{P}=0\end{array}$ & $\begin{array}{l}8.27, \mathrm{df}= \\
0.07)\end{array}$ & $=16(\mathrm{P}$ & $<0.0000$ & $1) ; I^{2}=80 \%$ & 0.01 & $\begin{array}{c}0.1 \\
\text { Favours [PTBD] }\end{array}$ & ${ }^{1} \underset{\text { Favours [EBD] }}{10}$ & 100 \\
\hline
\end{tabular}

Figure 3. Forest plot of comparison between EBD and PTBD; the outcome was odds ratio (OR) of overall complications.

\begin{tabular}{|c|c|c|c|c|c|c|c|c|c|}
\hline Study or Subgroup & \multicolumn{2}{|c|}{ PTBD } & \multicolumn{2}{|c|}{ EBD } & Weight & $\begin{array}{c}\text { Odds Ratio } \\
\text { M-H, Fixed, } 95 \% \mathrm{CI}\end{array}$ & \multicolumn{3}{|c|}{$\begin{array}{c}\text { Odds Ratio } \\
\text { M-H, Fixed, 95\% Cl }\end{array}$} \\
\hline CAI 2011 & 0 & 35 & 4 & 23 & $11.6 \%$ & $0.06[0.00,1.19]$ & $\leftarrow$ & & \\
\hline CHOI 2012 & 0 & 31 & 3 & 29 & $7.7 \%$ & $0.12[0.01,2.43]$ & $\leftarrow$ & & \\
\hline JO 2017 & 0 & 43 & 6 & 55 & $12.3 \%$ & $0.09[0.00,1.60]$ & $\leftarrow$ & 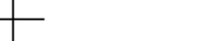 & \\
\hline KAWAKAMI 2011 & 0 & 48 & 1 & 20 & $4.5 \%$ & $0.13[0.01,3.43]$ & & & \\
\hline KIM 2015 & 0 & 62 & 9 & 44 & $23.9 \%$ & $0.03[0.00,0.53]$ & $\hookleftarrow$ & & \\
\hline KLOEK 2010 & 0 & 11 & 7 & 90 & $3.6 \%$ & $0.48[0.03,9.05]$ & & & \\
\hline LEE 2007 & 0 & 66 & 1 & 34 & $4.2 \%$ & $0.17[0.01,4.23]$ & & & \\
\hline MIURA 2017 & 0 & 25 & 6 & 63 & $8.0 \%$ & $0.17[0.01,3.20]$ & $\leftarrow$ & & \\
\hline PAIK 2009 & 2 & 41 & 0 & 44 & $1.0 \%$ & $5.63[0.26,120.91]$ & & & \\
\hline PINOL 2002 & 0 & 28 & 10 & 26 & $23.2 \%$ & $0.03[0.00,0.50]$ & & & \\
\hline Total $(95 \% \mathrm{Cl})$ & & 390 & & 428 & $100.0 \%$ & $0.14[0.06,0.31]$ & & & \\
\hline Total events & 2 & & 47 & & & & & & \\
\hline $\begin{array}{l}\text { Heterogeneity: } \mathrm{Chi}^{2} \\
\text { Test for overall effec }\end{array}$ & $\begin{array}{l}9.02, \mathrm{df} \\
\mathrm{Z}=4.82\end{array}$ & $\begin{array}{l}=9(P \\
2(P<0\end{array}$ & $\begin{array}{l}=0.44) ; \\
0.00001)\end{array}$ & $I^{2}=0 \%$ & & & $\begin{array}{c}1 \\
0.1 \\
\text { Favours [PTBD] }\end{array}$ & $\begin{array}{cc}1 & 10 \\
\text { Favours [EBD] }\end{array}$ & $\overrightarrow{100}$ \\
\hline
\end{tabular}

Figure 4. Forest plot of comparison between EBD and PTBD; the outcome was odds ratio (OR) of pancreatitis.

Statistical design. Meta-analyses were performed using the Review Manager (Rev-Man 5.3) software. Odds ratios (ORs) were used to analyze dichotomous variables, including technical success rate, risk of overall complications, 30-day mortality rate and risk of bleeding, pancreatitis, cholangitis and tube dislocation. Statistical heterogeneity between studies was examined using the Chi-square test and the $\mathrm{I}^{2}$ statistic. Substantial heterogeneity was considered to exist when the $\mathrm{I}^{2}$ value was greater than $50 \%$ or there was a low $p$-value $(<0.10)$ in the Chi-square test. When no heterogeneity was noted, the fixed effects model was used while the random effect model was applied in the presence of significant heterogeneity. Funnel plots were also constructed to look for potential publication bias.

\section{Results}

Studies selected. The search of electronic databases provided a total of 1206 potentially relevant reports. Additional 28 records were identified from conference proceedings and trial registries, with a total of 1234 search results. After adjusting for duplicates and excluding 1218 records as nonpertinent reports (meta-analyses, single-arm retrospective studies, case reports, systematic reviews, narrative reviews), the reports were restricted to 17 after independent evaluation by 2 authors (17-33). Figure 1 shows the search process. 


\begin{tabular}{|c|c|c|c|c|c|c|c|c|c|}
\hline Study or Subgroup & \multicolumn{2}{|c|}{ PTBD } & $\begin{array}{l}\text { EBD } \\
\text { Events } \\
\end{array}$ & Total & Weight & $\begin{array}{c}\text { Odds Ratio } \\
\mathrm{M}-\mathrm{H}, \text { Random, } 95 \% \mathrm{Cl}\end{array}$ & & \multicolumn{2}{|c|}{$\begin{array}{c}\text { Odds Ratio } \\
\text { M-H, Random, } 95 \% \mathrm{Cl}\end{array}$} \\
\hline CAI 2011 & 15 & 35 & 4 & 23 & $6.6 \%$ & $3.56[1.00,12.67]$ & & & \\
\hline CHOI 2012 & 4 & 31 & 5 & 87 & $6.2 \%$ & $2.43[0.61,9.70]$ & & & \\
\hline COELEN 2018 & 16 & 27 & 10 & 27 & $7.3 \%$ & $2.47[0.83,7.39]$ & & & \\
\hline HUANG 2015 & 5 & 45 & 12 & 55 & $7.2 \%$ & $0.45[0.14,1.38]$ & & & - \\
\hline JO 2017 & 7 & 43 & 14 & 55 & $7.6 \%$ & $0.57[0.21,1.57]$ & & & - \\
\hline KAWAKAMI 2011 & 5 & 48 & 13 & 20 & $6.5 \%$ & $0.06[0.02,0.23]$ & & & \\
\hline KIM 2015 & 5 & 62 & 16 & 44 & $7.3 \%$ & $0.15[0.05,0.46]$ & & & \\
\hline KISHI 2016 & 12 & 99 & 13 & 72 & $8.2 \%$ & $0.63[0.27,1.47]$ & & & - \\
\hline KLOEK 2010 & 1 & 11 & 43 & 90 & $4.1 \%$ & $0.11[0.01,0.89]$ & & & \\
\hline LEE 2007 & 8 & 66 & 10 & 34 & $7.5 \%$ & $0.33[0.12,0.94]$ & & & \\
\hline MIURA 2017 & 0 & 25 & 5 & 63 & $2.6 \%$ & $0.21[0.01,3.91]$ & & & \\
\hline PAIK 2009 & 9 & 41 & 13 & 44 & $7.7 \%$ & $0.67[0.25,1.79]$ & & & - \\
\hline SALUJA 2008 & 3 & 27 & 13 & 27 & $6.1 \%$ & $0.13[0.03,0.56]$ & & & \\
\hline SPEER 1987 & 5 & 33 & 7 & 37 & $6.7 \%$ & $0.77[0.22,2.69]$ & & & \\
\hline WALTER 2013 & 9 & 42 & 22 & 87 & $8.1 \%$ & $0.81[0.33,1.95]$ & & & \\
\hline Total $(95 \% \mathrm{Cl})$ & & 635 & & 765 & $100.0 \%$ & $0.52[0.30,0.90]$ & & & \\
\hline Total events & 104 & & 200 & & & & & & \\
\hline $\begin{array}{l}\text { Heterogeneity: } \mathrm{Tau}^{2} \\
\text { Test for overall effec }\end{array}$ & $\begin{array}{l}0.77 ; \mathrm{Ch} \\
\mathrm{Z}=2.33\end{array}$ & $\begin{array}{l}i^{2}=44 \\
(P=0\end{array}$ & $\begin{array}{l}4.58, \mathrm{df}= \\
.02)\end{array}$ & $=14(\mathrm{P}$ & $<0.0001$ & )$; I^{2}=69 \%$ & 0.01 & $\begin{array}{c}1 \\
0.1 \\
\text { Favours [PTBD] }\end{array}$ & $\begin{array}{r}10 \\
\text { Favours [EBD] }\end{array}$ \\
\hline
\end{tabular}

Figure 5. Forest plot of comparison between EBD and PTBD; the outcome was odds ratio (OR) of cholangitis.

\begin{tabular}{|c|c|c|c|c|c|c|c|c|c|c|}
\hline Study or Subgroup & $\begin{array}{l}\text { PTBL } \\
\text { Events }\end{array}$ & D Total & $\begin{array}{r}\text { EBD } \\
\text { Events }\end{array}$ & Total & Weight & \multicolumn{2}{|l|}{ Odds Ratio } & \multicolumn{2}{|c|}{$\begin{array}{c}\text { Odds Ratio } \\
\text { M-H, Fixed, 95\% Cl }\end{array}$} & \\
\hline CAI 2011 & 0 & 35 & 1 & 23 & $3.0 \%$ & $0.21[0.01,5.42]$ & & & & \\
\hline INAMDAR 2016 & 57 & 1690 & 137 & 7445 & $84.0 \%$ & $1.86[1.36,2.55]$ & & & & \\
\hline KIM 2015 & 1 & 62 & 3 & 44 & $5.9 \%$ & $0.22[0.02,2.23]$ & & & & \\
\hline KLOEK 2010 & 1 & 11 & 0 & 90 & $0.2 \%$ & $25.86[0.99,676.11]$ & & & & \\
\hline LEE 2007 & 5 & 66 & 2 & 34 & $4.2 \%$ & $1.31[0.24,7.14]$ & & & & \\
\hline PAIK 2009 & 2 & 41 & 0 & 44 & $0.8 \%$ & $5.63[0.26,120.91]$ & & & & \\
\hline SPEER 1987 & 1 & 33 & 0 & 37 & $0.8 \%$ & $3.46[0.14,87.94]$ & & & & \\
\hline WALTER 2013 & 1 & 42 & 1 & 87 & $1.1 \%$ & $2.10[0.13,34.38]$ & & & & \\
\hline Total $(95 \% \mathrm{Cl})$ & & 1980 & & 7804 & $100.0 \%$ & $1.78[1.32,2.39]$ & & & & \\
\hline Total events & 68 & & 144 & & & & & & & \\
\hline $\begin{array}{l}\text { Heterogeneity: } \mathrm{Chi}^{2}= \\
\text { Test for overall effec }\end{array}$ & $\begin{array}{l}8.29, \mathrm{df} \\
\mathrm{Z}=3.80\end{array}$ & $\begin{array}{l}=7(P \\
0(P=0\end{array}$ & $\begin{array}{l}=0.31) \text {; } \\
.0001)\end{array}$ & $I^{2}=16$ & & & 0.01 & $\begin{array}{c}0.1 \\
\text { Favours [PTBD] }\end{array}$ & Favours [ & $\begin{array}{c}10 \\
{[E B D]}\end{array}$ \\
\hline
\end{tabular}

Figure 6. Forest plot of comparison between EBD and PTBD; the outcome was odds ratio (OR) of bleeding.

Of the 17 eligible studies (17-33), thirteen retrospective studies $(19,21-32)$ and four RCTs $(17,18,20,33)$ were included, containing 2353 patients treated with PTBD and 8178 patients with EBD. Five studies were conducted in Korea $(19,21,25,28,31)$, three in Japan $(23,30,32)$, two in China $(24,27)$, two in Netherlands $(22,33)$, one in England (17), one in Spain (18), one in India (20), one in Canada (26) and one in USA (29). A summary of the included studies is presented in Table I.

Technical success rate. Ten studies reported the technical success rate of PTBD and EBD (17, 18, 20-22, 24-26, 28, $31)$. We compared technical success rate in the two groups and no significant differences were observed, with a pooled
OR of 2.15 (95\% CI=0.95-4.85) (Figure 2). The analysis was associated with a significant heterogeneity between trials $\left(\mathrm{I}^{2}=74 \%\right)$, so a random-effects model was used.

Procedure-related complications. All the studies (17-33) included in our meta-analysis reported the risk of overall complications in patients receiving PTBD or EBD and no significant differences were observed between the two groups, with an OR of 0.67 (95\% CI=0.43-1.03) (Figure 3). The analysis was associated with a substantial level of heterogeneity ( $\mathrm{I}^{2}$ value of $\left.80 \%\right)$ and a random-effects model was adopted.

Regarding the single complications, a lower risk of pancreatitis and cholangitis was reported in the PTBD group 


\begin{tabular}{|c|c|c|c|c|c|c|c|c|c|c|}
\hline Study or Subgroup & $\begin{array}{l}\text { PTBD } \\
\text { Events }\end{array}$ & Total & $\begin{array}{l}\text { EBD } \\
\text { Events }\end{array}$ & Total & Weight & $\begin{array}{c}\text { Odds Ratio } \\
\text { M-H, Random, } 95 \% \mathrm{CI}\end{array}$ & \multicolumn{4}{|c|}{$\begin{array}{c}\text { Odds Ratio } \\
\text { M-H, Random, } 95 \% \mathrm{CI}\end{array}$} \\
\hline CAI 2011 & 0 & 35 & 1 & 23 & $9.0 \%$ & $0.21[0.01,5.42]$ & $\hookleftarrow$ & & - & \\
\hline JO 2017 & 5 & 43 & 1 & 55 & $14.6 \%$ & $7.11[0.80,63.28]$ & & & & \\
\hline KAWAKAMI 2011 & 7 & 48 & 1 & 20 & $14.8 \%$ & $3.24[0.37,28.26]$ & & & & \\
\hline KIM 2015 & 3 & 62 & 9 & 44 & $21.3 \%$ & $0.20[0.05,0.78]$ & & & & \\
\hline KLOEK 2010 & 2 & 11 & 21 & 90 & $19.2 \%$ & $0.73[0.15,3.65]$ & & & & \\
\hline MIURA 2017 & 4 & 25 & 5 & 63 & $21.0 \%$ & $2.21[0.54,9.02]$ & & & & \\
\hline Total $(95 \% \mathrm{Cl})$ & & 224 & & 295 & $100.0 \%$ & $1.08[0.34,3.47]$ & & & & \\
\hline Total events & 21 & & 38 & & & & & & & \\
\hline $\begin{array}{l}\text { Heterogeneity: } \text { Tau }^{2} \\
\text { Test for overall effec }\end{array}$ & $\begin{array}{l}1.16 ; C h \\
Z=0.14\end{array}$ & $\begin{array}{l}i^{2}=1 \\
(P=0\end{array}$ & $\begin{array}{l}1.83, \mathrm{df}= \\
.89)\end{array}$ & $=5(P=$ & $=0.04) ; I^{2}$ & $=58 \%$ & 0.01 & $\begin{array}{c}0.1 \\
\text { Favours [PTBD] }\end{array}$ & 110 & 100 \\
\hline
\end{tabular}

Figure 7. Forest plot of comparison between EBD and PTBD; the outcome was odds ratio (OR) of tube dislocation.

\begin{tabular}{|c|c|c|c|c|c|c|c|c|c|c|}
\hline Study or Subgroup & $\begin{array}{r}\text { PTB } \\
\text { Events }\end{array}$ & PTBD & \multicolumn{2}{|l|}{ EBD } & Weight & $\begin{array}{c}\text { Odds Ratio } \\
\text { M-H, Fixed, 95\% Cl }\end{array}$ & \multicolumn{3}{|c|}{$\begin{array}{c}\text { Odds Ratio } \\
\text { M-H, Fixed, } 95 \% \mathrm{Cl}\end{array}$} & \\
\hline JO 2017 & 5 & 43 & 4 & 55 & $15.6 \%$ & $1.68[0.42,6.67]$ & & & & \\
\hline KIM 2015 & 3 & 62 & 2 & 44 & $11.2 \%$ & $1.07[0.17,6.67]$ & & & & \\
\hline LEE 2007 & 1 & 66 & 0 & 34 & $3.2 \%$ & $1.58[0.06,39.83]$ & & & & \\
\hline PAIK 2009 & 0 & 41 & 1 & 44 & $7.2 \%$ & $0.35[0.01,8.82]$ & & & & \\
\hline PINOL 2002 & 10 & 28 & 11 & 26 & $36.9 \%$ & $0.76[0.25,2.27]$ & & - & & \\
\hline SALUJA 2008 & 1 & 27 & 2 & 27 & $9.7 \%$ & $0.48[0.04,5.64]$ & & & & \\
\hline SPEER 1987 & 12 & 36 & 5 & 39 & $16.1 \%$ & $3.40[1.06,10.92]$ & & & & \\
\hline WALTER 2013 & 0 & 42 & 0 & 87 & & Not estimable & & & & \\
\hline Total $(95 \% \mathrm{Cl})$ & & 345 & & 356 & $100.0 \%$ & $1.33[0.75,2.38]$ & & & & \\
\hline Total events & 32 & & 25 & & & & & & & \\
\hline $\begin{array}{l}\text { Heterogeneity: } \mathrm{Chi}^{2} \\
\text { Test for overall effec }\end{array}$ & $\begin{array}{l}4.99, \mathrm{df} \\
Z=0.97\end{array}$ & $\begin{array}{l}=6(P \\
7(P=0\end{array}$ & $\begin{array}{l}=0.55) \\
.33)\end{array}$ & $I^{2}=0 \%$ & & & 0.01 & $\begin{array}{c}0.1 \\
\text { Favours [PTBD] }\end{array}$ & $\begin{array}{lr}1 & 10 \\
\text { Favours [EBD }\end{array}$ & 100 \\
\hline
\end{tabular}

Figure 8. Forest plot of comparison between EBD and PTBD; the outcome was odds ratio (OR) of 30-day mortality rate.

when compared with the EBD group, with a pooled OR of $0.14(95 \% \mathrm{CI}=0.06-0.31)(18,19,21-25,28,31,32)$ (Figure 4) and $0.52(95 \% \mathrm{CI}=0.30-0.90)(17,19-28,30-33)$ (Figure 5), respectively. On the contrary, PTBD showed a higher risk of bleeding (OR=1.78; 95\%CI=1.32-2.39) $(17,19,21,22,24$, 26, 28, 29) (Figure 6), compared with EBD. Given the substantial heterogeneity affecting the analysis on cholangitis, a random-effects model was used in this analysis.

Finally, the risk of tube dislocation did not differ between the two groups $(\mathrm{OR}=1.08 ; 95 \% \mathrm{CI}=0.34-3.47)(22-24,28,31$, 32) (Figure 7).

30-day mortality rate. Eight studies provided 30-day mortality rate in patients receiving PTBD or EBD (17-21, $26,28,31)$. The pooled OR for 30 -day mortality rate showed no differences between the two procedures giving OR 1.33 $\left(95 \% \mathrm{CI}=0.75-2.38, \mathrm{I}^{2}\right.$ value of $0 \%$ ) (Figure 8$)$.

Publication bias. Significant publication bias was detected for the therapeutic success rate, overall complications and cholangitis (Figures 9-15). The funnel plots on bleeding, tube dislocation, pancreatitis and 30-day mortality rate showed basic symmetry, suggesting no publication bias.

\section{Discussion}

MOJ represents a relatively frequent clinical condition in patients affected by primary or secondary hepato-biliopancreatic malignancies and it is considered a negative prognostic factor with important sequelae for quality of life and survival, regardless of the extent of the disease (34). In a retrospective study including patients with gallbladder cancer and who underwent surgical resection with curative intent, patients who presented MOJ showed poorer outcomes than patients without jaundice (35). Since the onset of jaundice is often insidious and silent, only about $20 \%$ of patients with MOJ can receive radical surgery because of the extent of the disease; for patients without surgical indications or for patients with unresectable malignant obstruction, percutaneous and endoscopic palliative procedures can relieve symptoms and improve quality of life (36). 


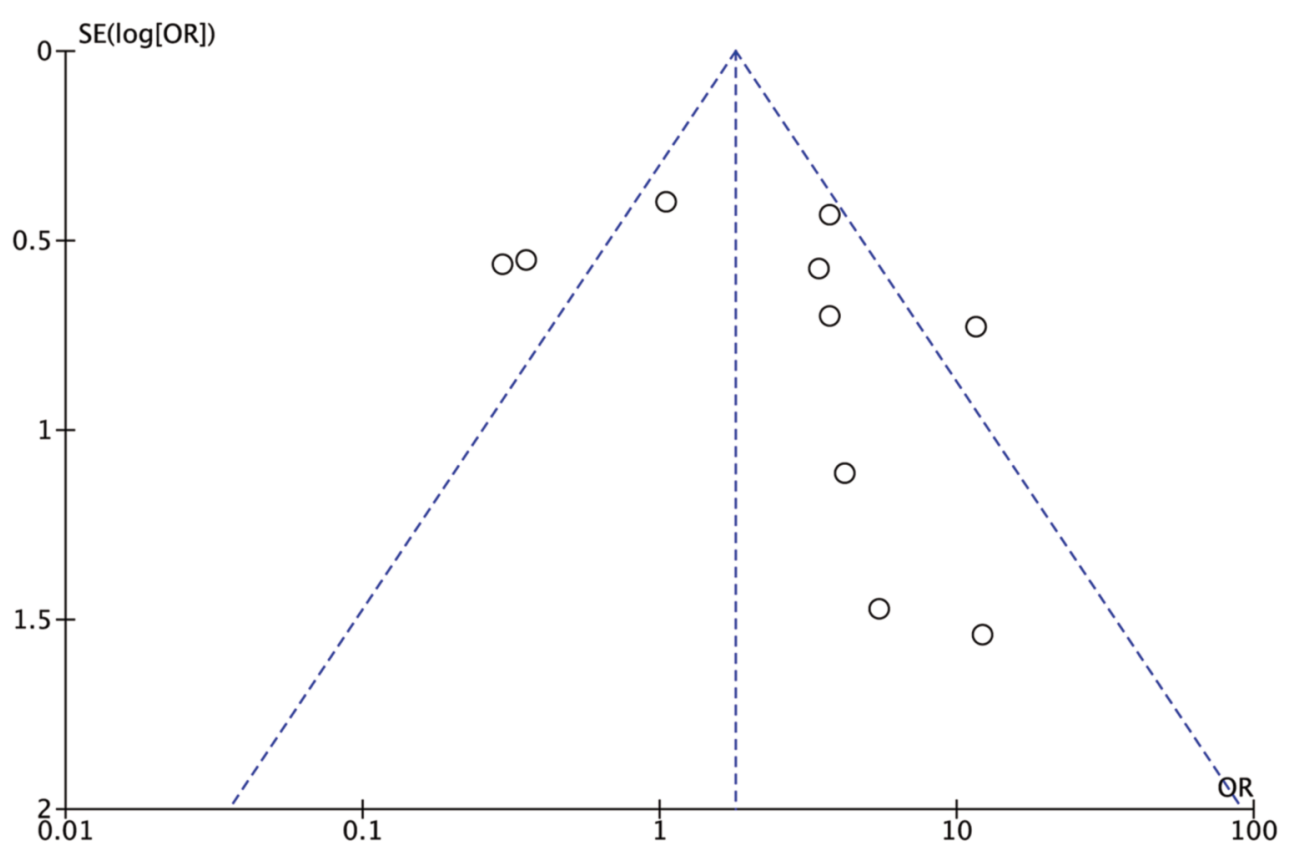

Figure 9. Funnel plot of therapeutic success rate.

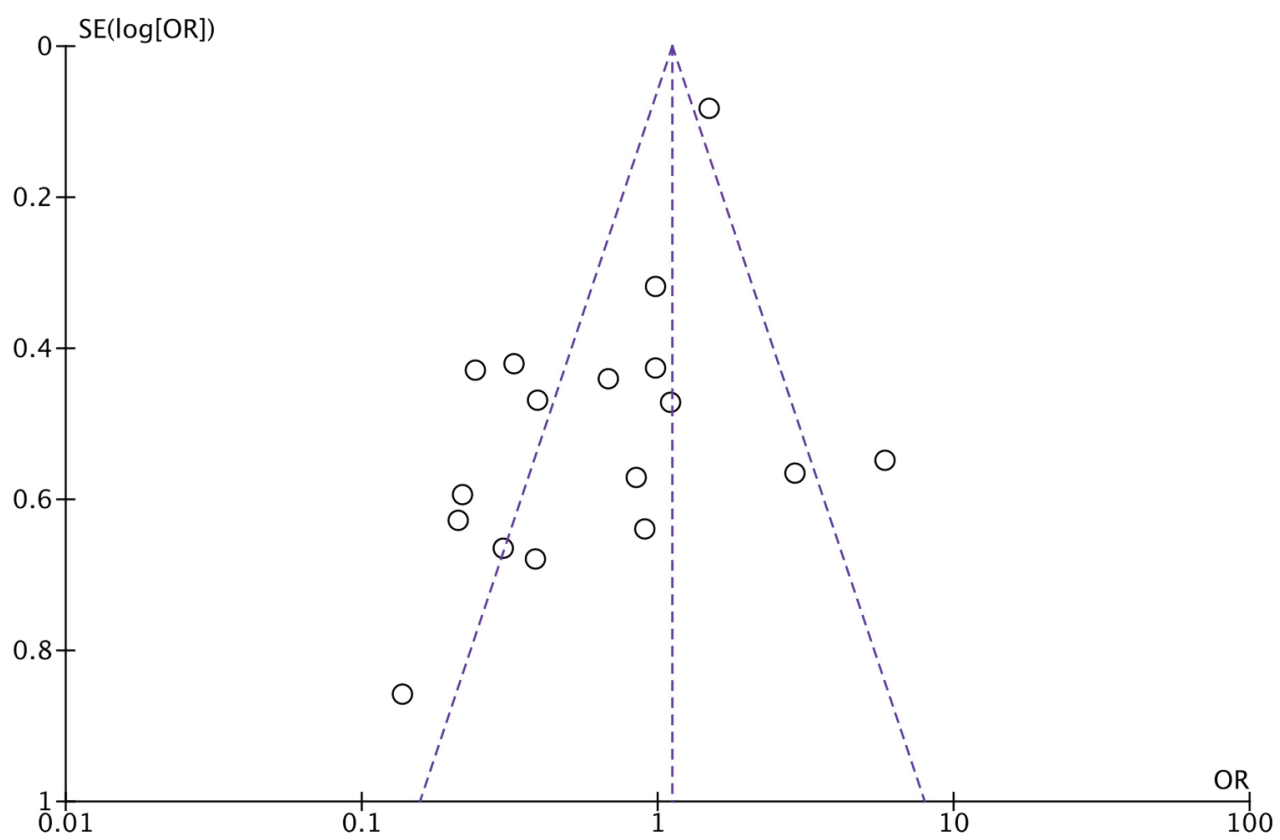

Figure 10. Funnel plot of overall complications.

In recent years, several studies investigated the efficacy and safety of PTBD and EBD in patients with MOJ $(37,38)$ and despite their increasing use in clinical practice, medical oncologists, interventional radiologists and gastroenterologists inevitably encounter doubts and difficulties in selecting the optimal technique. A multitude of parameters must be taken into consideration such as tumor location, patients' preferences, post-procedural therapeutic perspectives, purpose of drainage (as a palliative treatment or a preoperative procedure) and the availability of medical teams specialized 


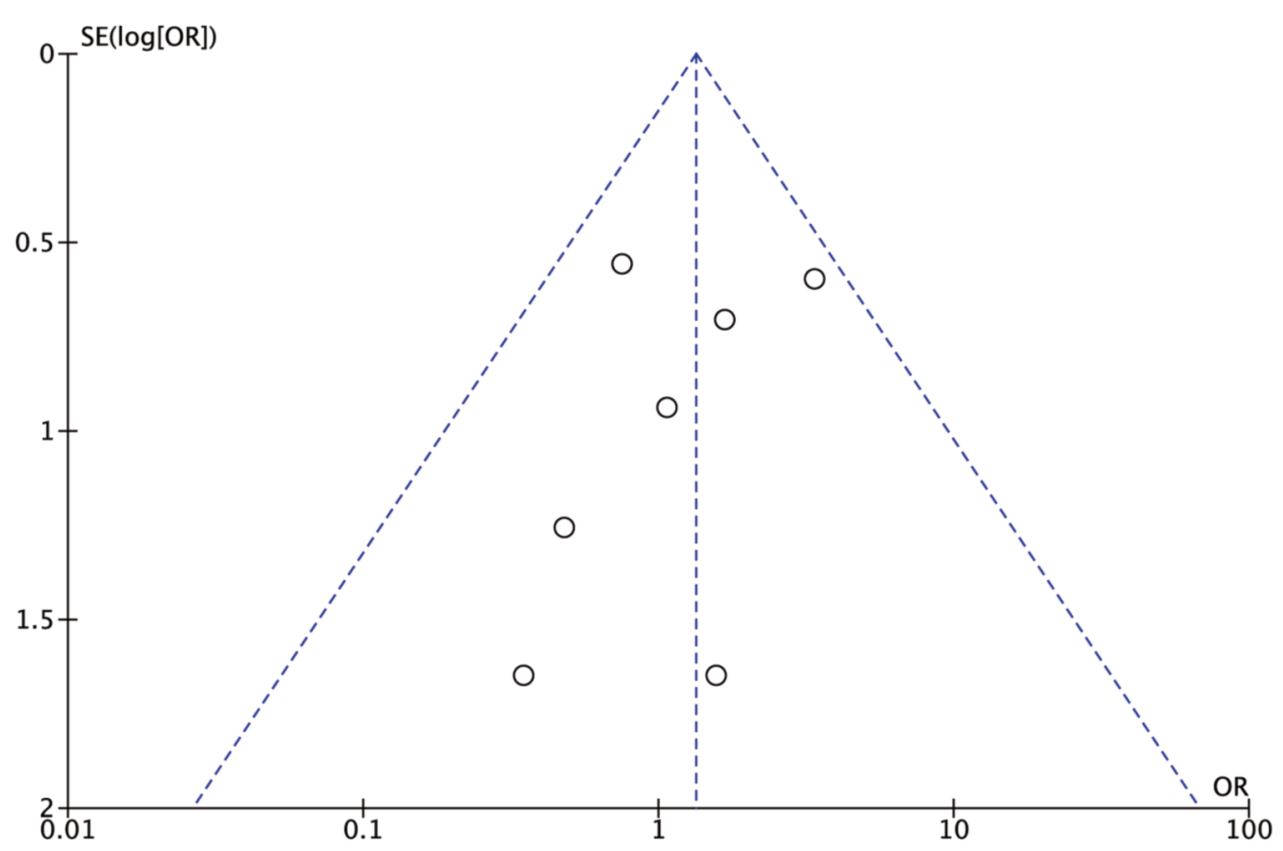

Figure 11. Funnel plot of 30-day mortality rate.

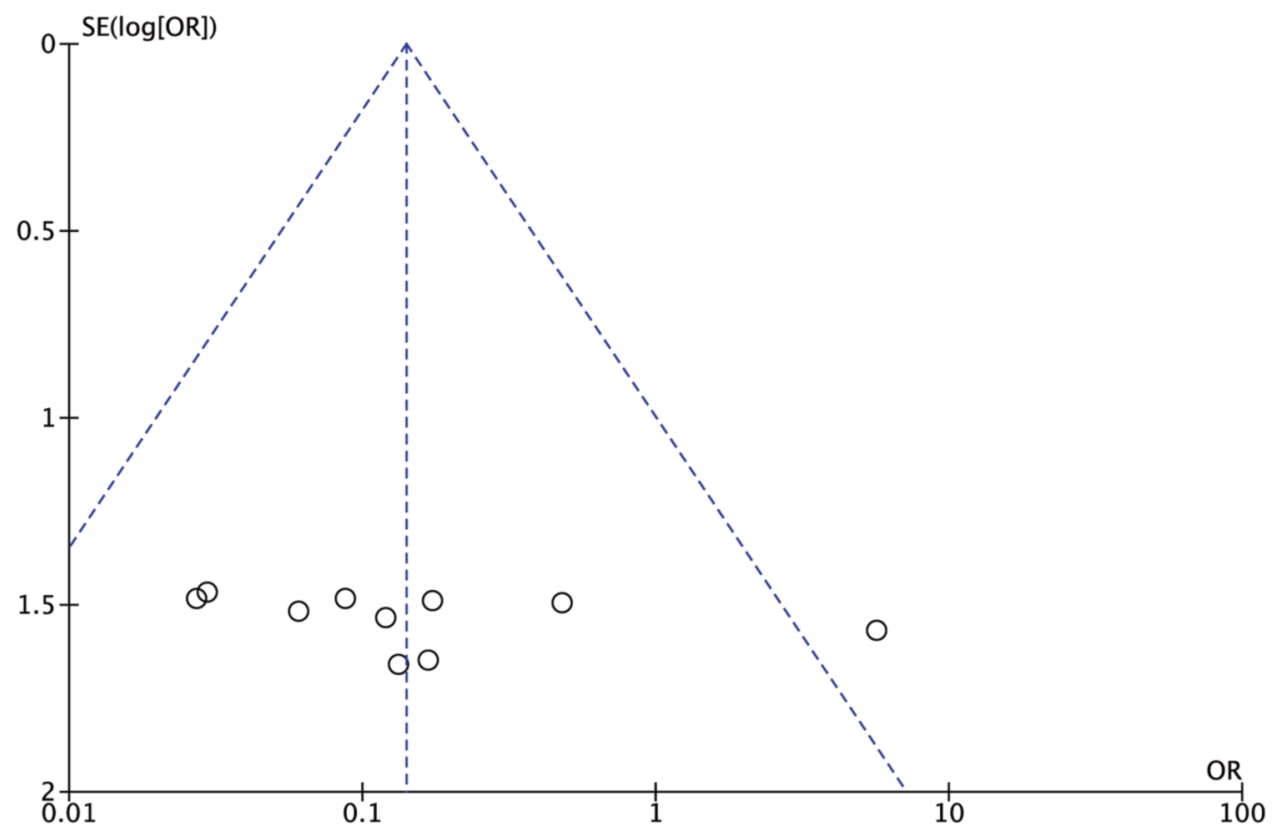

Figure 12. Funnel plot of pancreatitis.

in PTBD and EBD (39). EBD is usually preferred in case of distal biliary obstruction while patients with proximal obstruction often receive a percutaneous approach (40).

In our study, we performed a meta-analysis of 3 RCTs and 13 retrospective studies aimed at assessing the efficacy and safety of PTBD and EBD in MOJ. For these patients, the differences in technical success rate and in 30-day mortality rate were not statistically significant between the PTBD and the EBD treatment. Furthermore, the risk of total complications did not differ between the two groups 


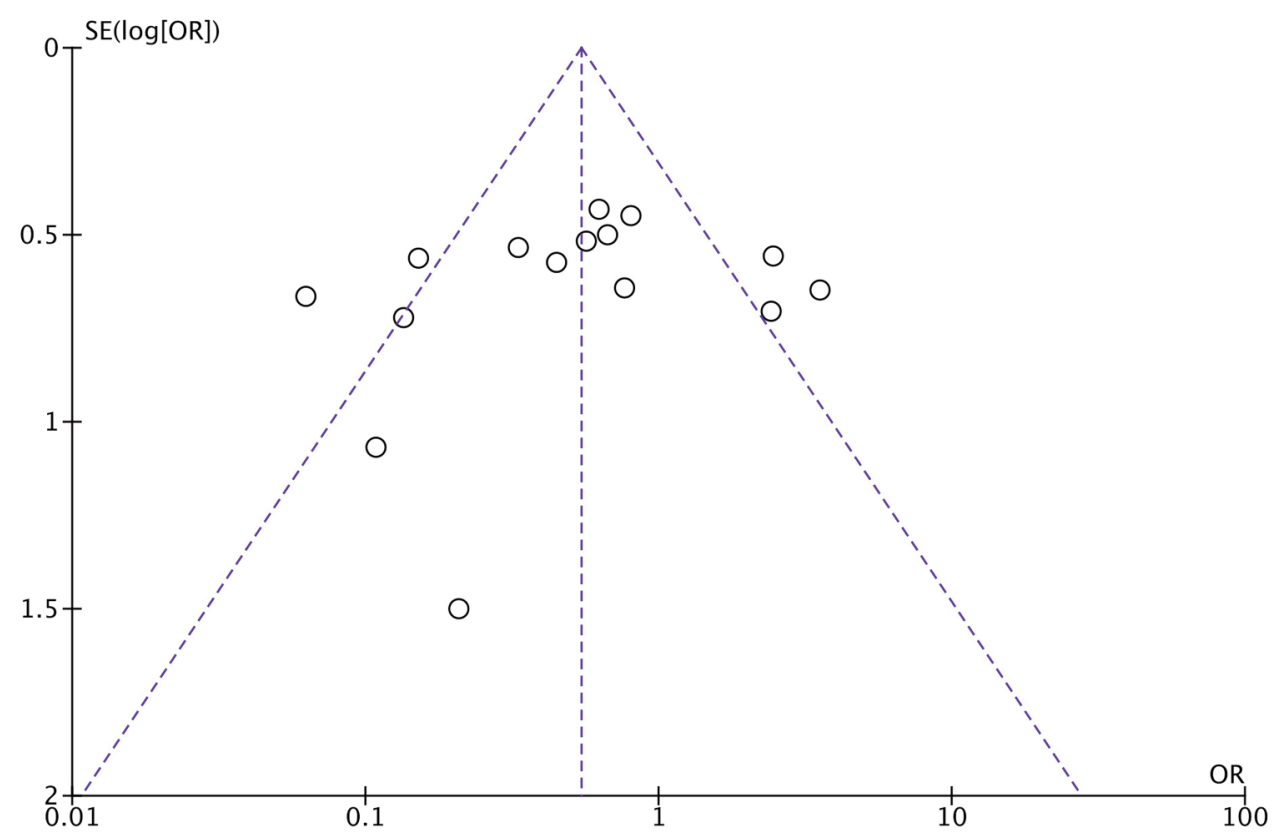

Figure 13. Funnel plot of cholangitis.

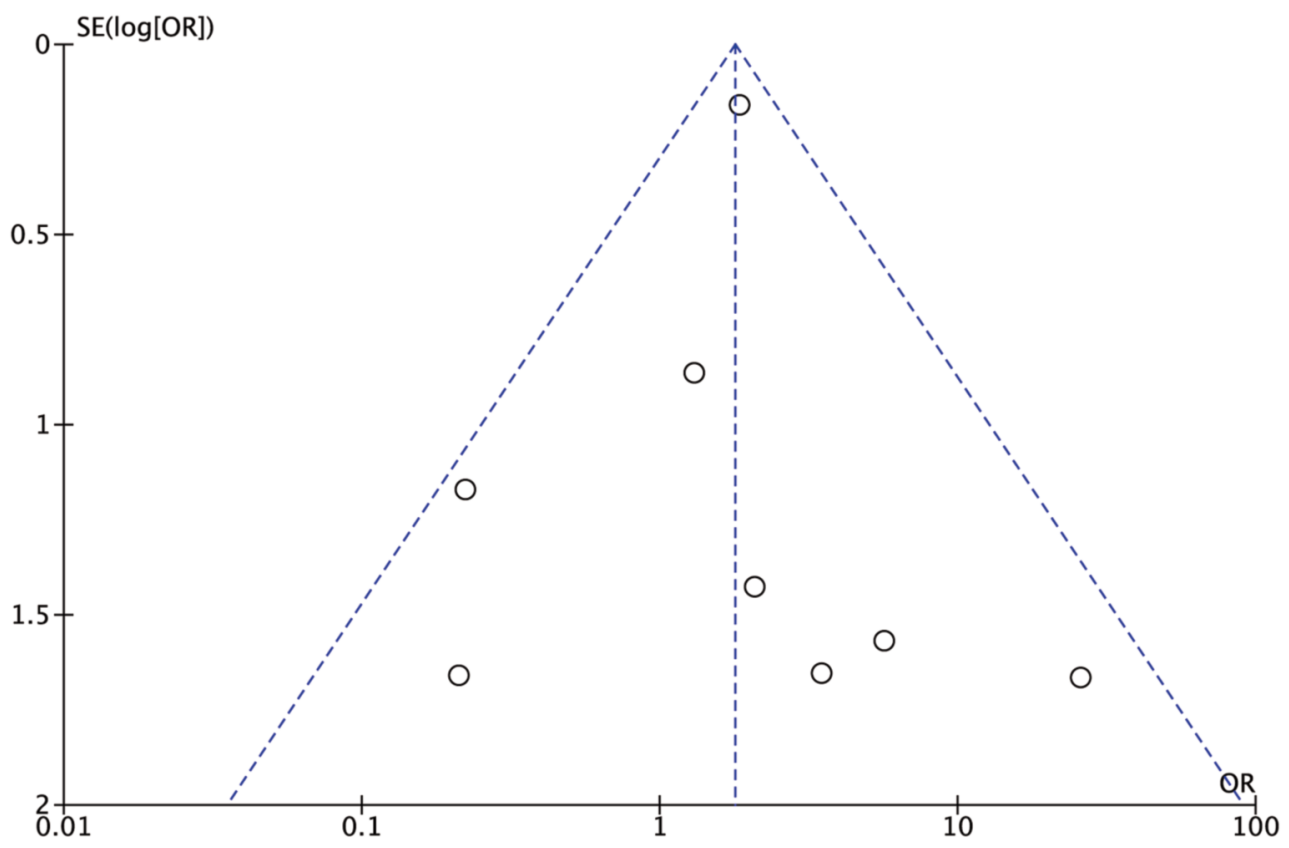

Figure 14. Funnel plot of bleeding.

although the safety profile revealed some significant differences.

In our analysis, PTBD resulted in a lower risk of pancreatitis and cholangitis when compared to EBD. Cholangitis and pancreatitis are relatively common complications which can occur despite prophylactic antibiotic coverage and which can result in biliary sepsis, a potentially lethal condition. Several factors may be involved in the onset of cholangitis and pancreatitis such as the retrograde entry of intestinal bacteria, the 


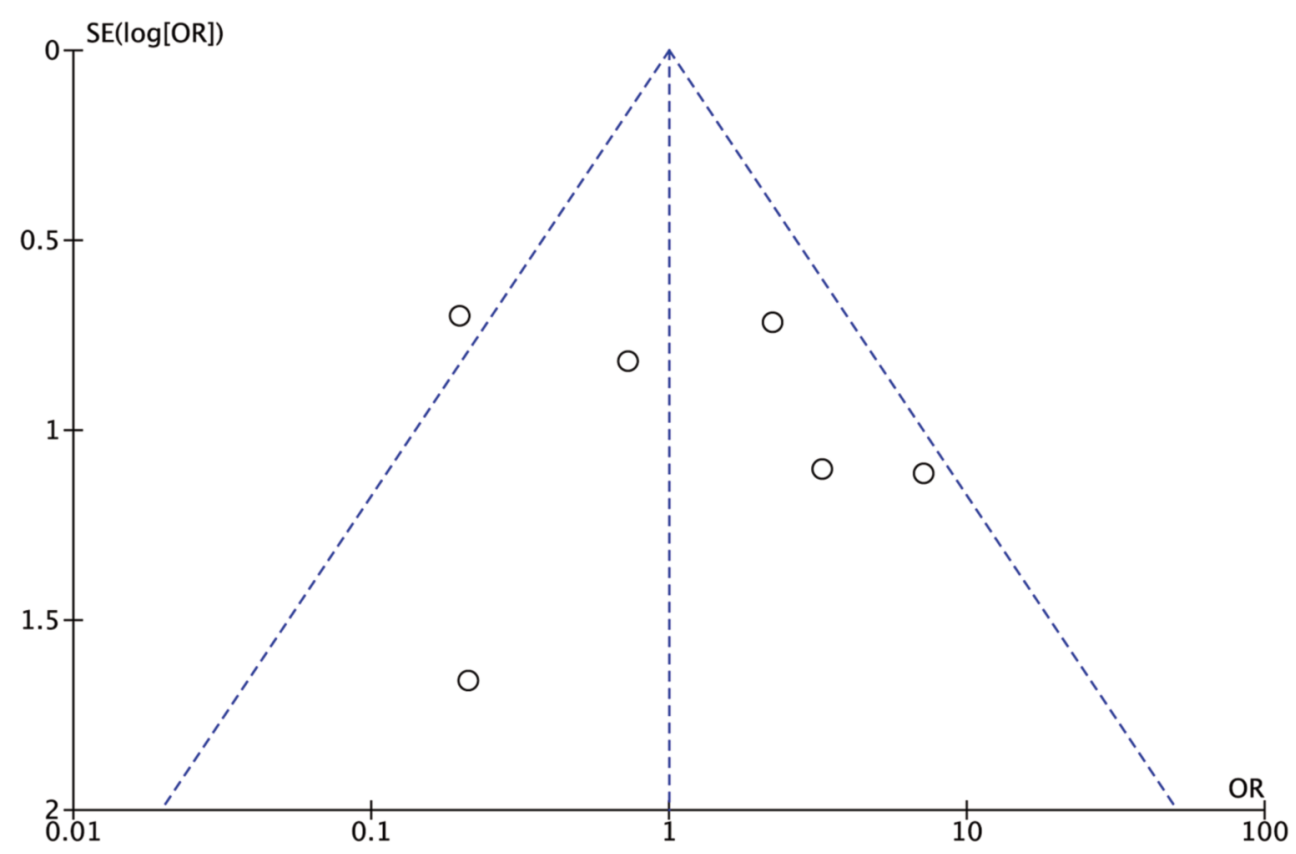

Figure 15. Funnel plot of tube dislocation.

manipulation of anatomical structures during the procedure, a pre-existing infection or poor general status (41). The higher risk of infection in EBD may also be explained by the procedure itself, which can damage the ampulla of Vater (or hepatopancreatic ampulla), the anatomical structure which prevents the retrograde flux of intestinal bacteria in biliary and pancreatic ducts, and whose damage dramatically increases the risk of infection (42). Moreover, in case of severe, difficult to handle obstructions, the drainage can only be partial, with subsequent bile stasis and higher risk of stasis-related secondary infections. Finally, the use of proton pump inhibitors (PPIs), some of the most frequently prescribed drugs worldwide, with subsequent hypochlorhydria, can influence duodenal bacterial flora and result in bacterial overgrowth in the duodenum (43-45); on this basis the use of EBD in patients receiving PPIs could be associated with an increased risk of phlogistic complications.

Our results are partially in line with previous metaanalysis by Duan et al. in 2017 (46), who evidenced a notstatistically significant difference between PTBD and EBD groups in terms of technical success rate, incidence of total complications and 30-day mortality rate. In this study, PTBD was associated with lower incidence of cholangitis and pancreatitis, compared to EBD which in turn resulted in lower incidence of bleeding and tube dislocation.

This meta-analysis holds its own strengths and limitations. The strengths of our meta-analysis include the large number of studies, the total number of patients
$(\mathrm{N}=10531)$ and the high-quality methodology of statistical analysis. However, the results of this meta-analysis should be interpreted with caution due to some limitations. Firstly, some analyses are burdened by publication bias and by a substantial level of heterogeneity which reflects the different types of studies as well as the various temporality and epidemiological data included. One of the weaknesses of our analysis is the inclusion of RCTs and retrospective studies held from 1987 to 2018, an important time period which undoubtedly can introduce bias to the results and significant confounding, given the technical improvements that occurred in the last thirty years. Secondly, geographical elements, primary tumor site, different purpose of drainage and the variable number of patients at different stages of the disease may represent other possible sources of heterogeneity. Thirdly, the studies did not include details concerning the type of stent (e.g. plastic or metal, uncovered or covered) used in PTBD and EBD. Moreover, only two $(27,31)$ of the selected studies reported data on sepsis and therefore we did not include this outcome in our analysis; regarding sepsis, large studies and data are needed to detect possible differences between the two techniques. Finally, only one of the selected studies included qualityof-life (QoL) data (20), reporting a trend towards a lower quality of life after EBD compared to PTBD. Given the steadily increasing importance of QoL issues in present-day clinical research, the paucity of QoL data represents a relevant issue who influences the management of patients with MOJ. 


\section{Conclusion}

Despite the limitations and the heterogeneities affecting our analyses, our study suggests that several outcomes do not statistically and significantly differ between PTBD and EBD in patients with MOJ. In fact, PTBD had comparable outcomes to EBD in terms of technical success rate, risk of total complications, 30-day mortality rate and risk of tube dislocation. PTBD was significantly superior to EBD in terms of lower risk of pancreatitis and cholangitis while EBD showed a lower risk of bleeding. All management of MOJ should be carried out within a multidisciplinary team setting. With a frequently poor long-term survival, future studies should be more focused on QoL-related outcomes in PTBD and EBD such as "time to deterioration" or "time of preservation of functional capacity or independence". In clinical practice, a reasonable approach should consider not only tumor location, purpose of procedure and expertise of the center but also a careful evaluation of medical history and clinical conditions (e.g. performance status, comorbidity, use of PPIs, hypochlorhydria) in order to individualize treatment recomme-ndations in the fragile population of patients with MOJ.

\section{Conflicts of Interest}

There are no conflicts of interest to declare regarding this study.

\section{Authors' Contributions}

Rizzo A: substantial contributions to conception of the study, analyzed the data and drafted the manuscript; Ricci AD: substantial contributions to conception of the study, analyzed the data and involved in revising the manuscript critically for important intellectual content; Frega G: substantial contributions to conception of the study and final approval of the version to be published; Palloni A: draft and revised the manuscript; De Lorenzo S: revised the manuscript; Abbati F: draft and revised the manuscript; Mollica V: revised the manuscript; Tavolari S: substantial contributions to conception of the study and revised the manuscript; Di Marco M: drafted the manuscript; Brandi G: involved in revising the manuscript critically for important intellectual content and has given final approval of the version to be published. All Authors critically revised the manuscript, approved the final version to be published, and agreed to be accountable for all aspects of the work.

\section{Acknowledgements}

The Author(s) received no financial support for the research, authorship, and/or publication of this article.

\section{References}

1 Sticova E and Jirsa M: New insights in bilirubin metabolism and their clinical implications. World J Gastroenterol 19(38): 63986407, 2013. PMID: 24151358. DOI: 10.3748/wjg.v19.i38.6398
2 Levitt DG and Levitt MD: Quantitative assessment of the multiple processes responsible for bilirubin homeostasis in health and disease. Clin Exp Gastroenterol 7: 307-328, 2014. PMID: 25214800. DOI: 10.2147/CEG.S64283

3 Nehez L and Andersson R: Compromise of immune function in obstructive jaundice. Eur J Surg 168(6): 315-328, 2002. PMID: 12428868. DOI: $10.1080 / 11024150260284815$

4 Sullivan JI and Rockey DC: Diagnosis and evaluation of hyperbilirubinemia. Curr Opin Gastroenterol 33(3): 164-170, 2017. PMID: 28333690. DOI: 10.1097/MOG.0000000000000354

5 Saluja SS, Sharma R, Pal SPS and Chattopadhyay TK: Differentiation between malignant and benign hilar obstructions using laboratory and radiological investigations: a prospective study. HPB 9: 373-382, 2007. PMID: 18345322. DOI: 10.1080/ 13651820701504207.

6 Casadei R, Ricci C, Giampalma E, D'Ambra M, Taffurelli G, Mosconi C, Golfieri R and Minni F: Interventional radiology procedures after pancreatic resections for pancreatic and periampullary diseases. JOP 15(4): 378-382, 2014. PMID: 25076347. DOI: $10.6092 / 1590-8577 / 2198$

7 De Lorenzo S, Tovoli F, Barbera MA, Garuti F, Palloni A, Frega G, Garajova I, Rizzo A, Trevisani F and Brandi G: Metronomic capecitabine vs. best supportive care in Child-Pugh B hepatocellular carcinoma: a proof of concept. Sci Rep, 8: 9997, 2018. PMID: 29968763. DOI: 10.1038/s41598-018-28337-6

8 Rizzo A, Frega G, Ricci AD, Palloni A, Abbati F, DE Lorenzo S, Deserti M, Tavolari S and Brandi G: Anti-EGFR monoclonal antibodies in advanced biliary tract cancer: a systematic review and meta-analysis. In Vivo 34(2): 479-488, 2020. PMID: 32111744. DOI: 10.21873/invivo.11798

9 Crosara Teixeira M, Mak MP, Marques DF, Capareli F, Carnevale FC, Moreira AM, Ribeiro U Jr, Cecconello I and Hoff PM: Percutaneous transhepatic biliary drainage in patients with advanced solid malignancies: Prognostic factors and clinical outcomes. J Gastrointest Cancer 44: 398-403, 2013. PMID: 23760941. DOI: 10.1007/s12029-013-9509-3

10 Lamarca A, Rigby C, McNamara MG, Hubner RA and Valle JW: Impact of biliary stent-related events in patients diagnosed with advanced pancreatobiliary tumours receiving palliative chemotherapy. World J Gastroenterol 22(26): 6065-6075, 2016. PMID: 27468198. DOI: 10.3748/wjg.v22.i26.6065

11 Hiratani S, Mori R, Ota Y, Matsuyama R, Kumamoto T, Nagashima Y, Morioka D and Endo I: A simple and easily reproducible model of reversible obstructive jaundice in rats. In Vivo 33(3): 699-706, 2019. PMID: 31028186. DOI: 10.21873/ invivo. 11528

12 Tapping CR, Byass OR and Cast JE: Percutaneous transhepatic biliary drainage (PTBD) with or without stenting-complications, re-stent rate and a new risk stratification score. Eur Radiol 21(9): 1948-1955, 2011. PMID: 21533867. DOI: 10.1007/s00330-0112121-7

13 Tsuyuguchi T, Takada T, Miyazaki M, Miyakawa S, Tsukada K, Nagino M, Kondo S, Furuse J, Saito H, Suyama M, Kimura F, Yoshitomi H, Nozawa M, Wada K, Amano H and Miura F: Stenting and interventional radiology for obstructive jaundice in patients with unresectable biliary tract carcinomas. J HepatoBiliary-Pancreat Surg 15(1): 69-73, 2008. PMID: 18274846. DOI: $10.1007 / \mathrm{s} 00534-007-1282-\mathrm{x}$

14 Al Mahjoub A, Menahem B, Fohlen A, Dupont B, Alves A, Launoy $\mathrm{G}$ and Lubrano J: Preoperative biliary drainage in 
patients with resectable perihilar cholangiocarcinoma: Is percutaneous transhepatic biliary drainage safer and more effective than endoscopic biliary drainage? A Meta-Analysis. J Vasc Interv Radiol 28(4): 576-582, 2017. PMID: 28343588. DOI: $10.1016 /$ j.jvir.2016.12.1218

15 Kurniawan J, Hasan I, Gani RA and Simadibrata M: Mortalityrelated factors in patients with malignant obstructive jaundice. Acta Med Indones 48(4): 282-288, 2016. PMID: 28143989.

16 Lombardi L, Troiano M, Silvestris N, Nanni L, Latiano TP, Di Maggio G, Cinieri S, Di Sebastiano P, Colucci G and Maiello E: Combined modality treatments in pancreatic cancer. Expert Opin Ther Targets 16: S71-81, 2012. PMID: 22443336. DOI: $10.1517 / 14728222.2012 .662959$

17 Speer AG, Cotton PB, Russell RC, Mason RR, Hatfield AR, Leung JW, Houghton J and Lennon CA: Randomised trial of endoscopic versus percutaneous stent insertion in malignant obstructive jaundice. Lancet 2(8550): 57-62, 1987. PMID: 2439854. DOI: $10.1016 / \mathrm{S} 0140-6736(87) 92733-4$

18 Piñol V, Castells A, Bordas JM, Real MI, Llach J, Montañà X, Feu F and Navarro S: Percutaneous self-expanding metal stents versus endoscopic polyethylene endoprostheses for treating malignant biliary obstruction: randomized clinical trial. Radiology 225(1): 27-34, 2002. PMID: 12354980. DOI: 10.1148/radiol.2243011517

19 Lee SH, Park JK, Yoon WJ, Lee JK, Ryu JK, Yoon YB and Kim YT: Optimal biliary drainage for inoperable Klatskin's tumor based on Bismuth type. World J Gastroenterol 13(29): 39483955, 2007. PMID: 17663508. DOI: 10.3748/wjg.v13.i29.3948

20 Saluja SS, Gulati M, Garg PK, Pal H, Pal S, Sahni P and Chattopadhyay TK: Endoscopic or percutaneous biliary drainage for gallbladder cancer: a randomized trial and quality of life assessment. Clin Gastroenterol Hepatol 6(8): 944-950.e3, 2008. PMID: 18585976. DOI: 10.1016/j.cgh.2008.03.028

21 Paik WH, Park YS, Hwang JH, Lee SH, Yoon CJ, Kang SG, Lee JK, Ryu JK, Kim Y and Yoon YB: Palliative treatment with selfexpandable metallic stents in patients with advanced type III or IV hilar cholangiocarcinoma: a percutaneous versus endoscopic approach. Gastrointest Endosc 69(1): 55-62, 2009. PMID: 18657806. DOI: 10.1016/j.gie.2008.04.005

22 Kloek JJ, van der Gaag NA, Aziz Y, Rauws EA, van Delden OM, Lameris JS, Busch OR, Gouma DJ and van Gulik TM: Endoscopic and percutaneous preoperative biliary drainage in patients with suspected hilar cholangiocarcinoma. J Gastrointest Surg 14(1): 119-125, 2010. PMID: 19756881. DOI: 10.1007/s11605-009-1009-1

23 Kawakami H, Kuwatani M, Onodera M, Haba S, Eto K, Ehira N, Yamato H, Kudo T, Tanaka E, Hirano S, Kondo S and Asaka M: Endoscopic nasobiliary drainage is the most suitable preoperative biliary drainage method in the management of patients with hilar cholangiocarcinoma. J Gastroenterol 46(2): 242-248, 2011. PMID: 20700608. DOI: 10.1007/s00535-010-0298-1

24 Cai YF, Su SY, Cui WZ, Fei L and Li JY: Selection of preoperative biliary drainage procedure for resect- able hilar cholangiocarcinoma. Chin J Gen Surg 8: 844847, 2011.

25 Choi J, Ryu JK, Lee SH, Ahn DW, Hwang JH, Kim YT, Yoon YB and Han JK: Biliary drainage for obstructive jaundice caused by unresectable hepatocellular carcinoma: the endoscopic versus percutaneous approach. Hepatobiliary Pancreat Dis Int 11(6): 636-642, 2012. PMID: 23232636. DOI: 10.1016/s14993872(12)50237-9
26 Walter T, Ho CS, Horgan AM, Warkentin A, Gallinger S, Greig PD, Kortan P and Knox JJ. Endoscopic or percutaneous biliary drainage for Klatskin tumors? J Vasc Interv Radiol 24(1): 113-121, 2013. PMID: 23182938. DOI: 10.1016/j.jvir. 2012.09.019

27 Huang X, Liang B, Zhao XQ, Zhang FB, Wang XT and Dong JH: The effects of different preoperative biliary drainage methods on complications following pancreaticoduodenectomy. Medicine (Baltimore) 94(14): e723, 2015. PMID: 25860221. DOI: $10.1097 / \mathrm{MD} .0000000000000723$

28 Kim KM, Park JW, Lee JK, Lee KH, Lee KT and Shim SG: A comparison of preoperative biliary drainage methods for perihilar cholangiocarcinoma: endoscopic versus percutaneous transhepatic biliary drainage. Gut Liver 9(6): 791-799, 2015. PMID: 26087784. DOI: 10.5009/gnl14243

29 Inamdar S, Slattery E, Bhalla R, Sejpal DV and Trindade AJ: Comparison of adverse events for endoscopic vs percutaneous biliary drainage in the treatment of malignant biliary tract obstruction in an Inpatient National Cohort. JAMA Oncol 2(1): 112-117, 2016. PMID: 26513013. DOI: $10.1001 /$ jamaoncol.2015.3670

30 Kishi Y, Shimada K, Nara S, Esaki M and Kosuge T: The type of preoperative biliary drainage predicts short-term outcome after major hepatectomy. Langenbecks Arch Surg 401(4): 503511, 2016. PMID: 27074727. DOI: 10.1007/s00423-016-1427-y

31 Jo JH, Chung MJ, Han DH, Park JY, Bang S, Park SW, Song SY and Chung JB: Best options for preoperative biliary drainage in patients with Klatskin tumors. Surg Endosc 31(1): 422-429, 2017. PMID: 27287904. DOI: 10.1007/s00464-016-4993-8

32 Miura F, Sano K, Wada K, Shibuya M, Ikeda Y, Takahashi K, Kainuma M, Kawamura S, Hayano K and Takada T: Prognostic impact of type of preoperative biliary drainage in patients with distal cholangiocarcinoma. Am J Surg 214(2): 256-261, 2017. PMID: 28108067. DOI: 10.1016/j.amjsurg.2017.01.010

33 Coelen RJS, Roos E, Wiggers JK, Besselink MG, Buis CI, Busch ORC, Dejong CHC, van Delden OM, van Eijck CHJ, Fockens P, Gouma DJ, Koerkamp BG, de Haan MW, van Hooft JE, Ijzermans JNM, Kater GM, Koornstra JJ, van Lienden KP, Moelker A, Damink SWMO, Poley JW, Porte RJ, de Ridder RJ, Verheij J, van Woerden V, Rauws EAJ, Dijkgraaf MGW and van Gulik TM: Endoscopic versus percutaneous biliary drainage in patients with resectable perihilar cholangiocarcinoma: a multicentre, randomised controlled trial. Lancet Gastroenterol Hepatol 3(10): 681-690, 2018. PMID: 30122355. DOI: 10.1016/S2468-1253(18)30234-6

34 Khan SA, Tavolari S and Brandi G: Cholangiocarcinoma: Epidemiology and risk factors. Liver Int 39: 19-31, 2019. PMID: 30851228. DOI: 10.1111/liv.14095

35 Yang XW, Yang J, Li L, Man XB, Zhang BH, Shen F and Wu MC: Analysis of the relationships between clinicopathologic factors and survival in gallbladder cancer following surgical resection with curative intent. PLoS One 7(12): e51513, 2012. PMID: 23300551. DOI: 10.1371/journal.pone.0051513

36 Vogel A, Kullmann F, Kunzmann V, Al-Batran SE, Oettle H, Plentz R, Siveke J, Springfield C and Riess H: Patients with advanced pancreatic cancer and hyperbilirubinaemia: review and german expert opinion on treatment with nabpaclitaxel plus gemcitabine. Oncol Res Treat 38(11): 596-603, 2015. PMID: 26599274. DOI: 10.1159/000441310

37 Yasumoto T, Yokoyama S and Nagaike K: Percutaneous transcholecystic metallic stent placement for malignant 
obstruction of the common bile duct: preliminary clinical evaluation. J Vasc Interv Radiol 21: 252-258, 2010. PMID: 20123209. DOI: 10.1016/j.vir.2009.10.010

38 Walter T, Ho CS, Horgan AM, Warkentin A, Gallinger S, Greig PD, Kortan P and Knox JJ: Endoscopic or percutaneous biliary drainage for Klatskin tumors? J Vasc Interv Radiol 24: 113-121, 2013. PMID: 23182938. DOI: 10.1016/J.VIR.2012.09.019.

39 George C, Byass OR and Cast JE: Interventional radiology in the management of malignant biliary obstruction. World $\mathrm{J}$ Gastrointest Oncol 2: 146-150, 2010. PMID: 21160822. DOI: 10.4251/wjgo.v2.i3.146

40 Iacono C, Ruzzenente A, Campagnaro T, Bortolasi L, Valdegamberi A and Guglielmi A: Role of preoperative biliary drainage in jaundiced patients who are candidates for pancreatoduodenectomy or hepatic resection: highlights and drawbacks. Ann Surg 257(2): 191-204, 2013. PMID: 23013805. DOI: $10.1097 /$ SLA.0b013e31826f4b0e

41 Tierney J, Bhutiani N, Stamp B, Richey JS, Bahr MH and Vitale GC: Predictive risk factors associated with cholangitis following ERCP. Surg Endosc 32(2): 799-804, 2018. PMID: 28733732. DOI: $10.1007 / \mathrm{s} 00464-017-5746-\mathrm{z}$

42 Talukdar R: Complications of ERCP. Best Pract Res Clin Gastroenterol 30(5): 793-805, 2016. PMID: 27931637. DOI: 10.1016/j.bpg .2016.10.007
43 Lo WK and Chan WW: Proton pump inhibitor use and the risk of small intestinal bacterial overgrowth: a meta-analysis. Clin Gastroenterol Hepatol 11(5): 483-490, 2013. PMID: 23270866. DOI: $10.1016 /$ j.cgh.2012.12.011

44 Miozzo SAS, John JA, Appel-da-Silva MC, Dossin IA, Tovo CV and Mattos AA: Influence of proton pump inhibitors in the development of spontaneous bacterial peritonitis. World J Hepatol 9(35): 1278-1285, 2017. PMID: 29290909. DOI: 10.4254/wjh.v9.i35.1278

45 Brandi G, Biavati B, Calabrese C, Granata M, Nannetti A, Mattarelli P, Di Febo G, Saccoccio G and Biasco G: Ureasepositive bacteria other than Helicobacter pylori in human gastric juice and mucosa. Am J Gastroenterol 101(8): 1756-1761, 2006. PMID: 16780553. DOI: 10.1111/j.1572-0241.2006.00698.x

46 Duan F, Cui L, Bai Y, Li X, Yan J and Liu X: Comparison of efficacy and complications of endoscopic and percutaneous biliary drainage in malignant obstructive jaundice: a systematic review and meta-analysis. Cancer Imaging 17(1): 27, 2017. PMID: 29037223. DOI: 10.1186/s40644-017-0129-1

Received March 26, 2020

Revised March 31, 2020

Accepted April 1, 2020 